\title{
Health Consciousness and Brand Equity in the Carbonated Soft Drink Industry in Sri Lanka
}

\author{
Vadivelu Thusyanthy ${ }^{1}$ \\ ${ }^{1}$ Department of Economics and Management, Vavuniya Campus of the University of Jaffna, Vavuniya, Sri \\ Lanka \\ Correspondence: Vadivelu Thusyanthy, Department of Economics and Management, Vavuniya Campus of the \\ University of Jaffna, Pambaimaddu, Vavuniya, Sri Lanka. E-mail: thusi86@vau.jfn.ac.lk
}

Received: November 18, 2017

Accepted: January 22, 2018

Online Published: February 25, 2018

doi:10.5539/ijbm.v13n3p188

URL: https://doi.org/10.5539/ijbm.v13n3p188

\begin{abstract}
The purpose of this study is to assess the degree of health consciousness and customer based brand equity, and this study aims to consider further the impact of health consciousness on customer based brand equity by using the health belief model theory and brand value concept in the carbonated soft drink industry in Sri Lanka. A total of 338 usable data were collected from undergraduate students at universities in Sri Lanka. In analyzing the empirical data one sample t-test and simple linear regression analysis were used. The results show that the degree of health consciousness and customer based brand equity are in low level and moderate level, respectively, whilst health consciousness has significant positive impact on customer based brand equity. The findings of this study regarding the levels of health consciousness and customer based brand equity and the impact of health consciousness on customer based brand equity have important implications for marketing managers in the carbonated soft drink industry in Sri Lanka.
\end{abstract}

Keywords: health consciousness, customer based brand equity, health belief model, brand value, carbonated soft drink, Sri Lanka

\section{Introduction}

Food and beverage industry is one of the vital industries and largest contributors to the world and Sri Lankan economy (Gehlhar \& Rrgmi, 2005; Peiris, 2014). Soft drinks sector is one of the fastest growing, most innovative and rapidly changing areas in the food and beverage industry (Central Bank of Sri Lanka, 2011; Leatherhead Food Research, 2014), while carbonated soft drink sector represents the largest segment of the global as well as Sri Lankan soft drink sector (Bloomberg, 2011; Bruce, 2011; Pamnani, Pellerano, Sivajee \& Tambiah, 2004). In fact, per capita consumption of carbonated soft drinks in Sri Lanka is 21 bottles compared to India's 5 bottles and Pakistan's 17 bottles (NIIR Project Consultancy Services, 2012), with 62 million liters of carbonated soft drink consumed by Sri Lankans per year (Bruce, 2011), thus, carbonated soft drink industry is one of the growing industries in Sri Lanka, especially among the educated youth generation. Even though the carbonated soft drink industry is the important sector in the soft drink industry, there are, however, few published studies in the Sri Lankan context related to carbonated soft drink industry, especially among the educated youth generation, and this is the main intention for conducting this empirical study mainly in this sector. Further, carbonated soft drink industry in Sri Lanka is dominated by three key players namely, Elephant House, Coca Cola and Pepsi Cola (Mendis, 2012; The Sunday Leader, 2010).

Although carbonated soft drink industry one of the significant and growing industries across the world and Sri Lanka, nowadays consumers are highly concerned about their health, which is related to the consumption of carbonated soft drinks, since carbonated soft drinks generally contain a high amount of refined sugar and therefore, they have high calorie content (Hu \& Malik, 2010; as Lörinczi, Bács, \& Nagy, 2009 cites Minnesota Department of Health, 2005). Consequently, the consumption of carbonated soft drinks has a harmful dietary effect, and therefore, the $\mathrm{HC}$ of the consumers towards the consumption of carbonated soft drinks have been increased (Lörinczi et al., 2009), but what is the degree of youth educated consumers' HC in the carbonated soft drink industry in Sri Lanka? Previous published researches do not answer this question in the Sri Lankan context.

Kemp and Bui (2011) argue that, due to the HC, individuals purchase branded products and therefore, it leads to 
brand equity. Though, brand equity is focused on three perspectives, namely financial (Haigh, 1999), company (Keller, 2003) and customer (Aaker, 1991), this study considers brand equity in the customer's perspective. This customer based brand equity (CBBE) performs a vital role in the carbonated soft drink industry (Waris, 2013), but what is the degree of youth educated consumers' perceived evaluation on brand equity in the carbonated soft drink industry in Sri Lanka? Extant published research does not answer this question.

The rest of this study is organized as follows: the next section literature review and conceptual framework, followed by methodology, data analysis and results, and discussion. The final section offers the limitations and further research directions.

\section{Literature Review and Conceptual Framework}

\subsection{Health Consciousness}

$\mathrm{HC}$ of the consumers is becoming a vital factor over the last few decades. Bhangale (2011) argues that health is the condition of a person's body (e.g., a person living without illness) and consciousness is the knowledge or understanding about existence of something or importance of something, therefore $\mathrm{HC}$ refers to a comprehensive orientation of individual towards health, rather than the issues related to specific orientations such as smoking and weight control. Gould (1990) defines HC as inner status of a person regarding the health.

It is important to note that there is a growing segment of health conscious consumers across the world (Kemp \& Bui, 2011). In fact, consumer's HC towards the consumption of soft drinks (especially carbonated soft drinks) is increased (Lörinczi et al., 2009), since carbonated soft drinks consumption has a harmful dietary effect to the human body and it will lead to the risk of obesity, diabetes, cardiovascular disease, and fatty liver disease (e.g., Assy et al., 2008; Davis et al., 2005; Palmer, Boggs, Krishnan, Hu, Singer \& Rosenberg, 2008). In addition, Sri Lankan consumers have now rapidly become more health conscious towards consumption of food and beverage (e.g., Cader, 2014; Perera, 2012). However, there has been no recent systematic data available that is related to the level of $\mathrm{HC}$ of consumers in the carbonated soft drink industry in Sri Lanka, especially among the educated youth generation. In addition, generally, the $\mathrm{HC}$ is high degree in the carbonated soft drink industry across the world, and Sri Lankan consumer's, especially among the educated youth generation $\mathrm{HC}$ is also high degree towards the consumption of food and beverage, and thus, the researcher assumed that the HC is high degree in the carbonated soft drink industry in Sri Lanka, especially among the educated youth generation. According to the above argument the first hypothesis has been formulated.

H1: The degree of youth educated consumers' $\mathrm{HC}$ is at a high level in the carbonated soft drink industry in Sri Lanka.

Consumers purchase branded products since they desire to live a healthier life (Shavitt, Torelli \& Wong, 2009). Therefore, Kemp and Bui (2011) argue that, due to the HC, individuals purchase branded products and therefore, it leads to brand equity.

\subsection{Customer Based Brand Equity}

Aaker (1991) defines brand equity is 'a set of brand assets and liabilities linked to a brand, its name and symbol that add to or subtract from the value provided by a product or service to a firm and/or that firm's customers'.

Although brand equity focuses on three perspectives, namely financial, company and customer based, this study considers the brand equity in the customer's perspective, whilst many previous studies consider CBBE (e.g., Aaker, 1991; Pradhan \& Misra, 2014). Pappu, Quester and Cooksey (2006) defines CBBE as 'the value consumers associate with a brand, as reflected in the dimensions of brand awareness, brand associations, perceived quality and brand loyalty'.

The CBBE performs a vital role in the beverage industry (Atilgan, Aksoy \& Akinci, 2005), and Waris (2013) and Huang and Liu (2014) imply that CBBE is particularly important to the carbonated soft drink industry. Though there has been no recent statistics available to show the level of CBBE in the Sri Lankan carbonated soft drink industry, and Coca Cola, Elephant House and Pepsi Cola have more brand value within the carbonated soft drink industry in Sri Lanka in 2014 (Brand Finance Lanka, 2014), since Kamakura and Russell (1993) affirm that high brand value is vital for and creates high degree of CBBE. Therefore, the researcher assumed that the CBBE is at a high degree in the carbonated soft drink industry in Sri Lanka, especially among the educated youth generation due to the higher brand value for Coca Cola, Elephant House and Pepsi Cola. According to the above argument the second hypothesis is advanced.

$\mathrm{H} 2$ : The degree of youth educated consumers' perceived evaluation on brand equity is at a higher level in the carbonated soft drink industry in Sri Lanka. 


\subsection{Health Consciousness-Customer Based Brand Equity: Theoretical Foundation}

The relationship between $\mathrm{HC}$ and $\mathrm{CBBE}$ is explained by using the health belief model theory and brand value concept (e.g., Becker, Drachman \& Kirscht, 1974; Dawar, 1998; Dawar \& Pillutla, 2000; Kamakura \& Russell, 1993; Narayana, 2009). In fact, the health belief model theory is rooted from a well established body of psychological and behavioral theory (Janz \& Becker, 1984) and it is designed by Hochbaum et al. in the 1950s (Glanz \& Rimer, 1995; Janz \& Becker, 1984; Rosenstock, 1974). This model contributes to the health behavior concept and it is used to develop HC scale (e.g., Narayana, 2009). Hence, the health belief model theory supports the concept of HC of consumers (e.g., Narayana, 2009; Rosenstock, Strecher \& Becker, 1988).

According to the health belief model theory people expect health actions to prevent illness, since they do not want to get sick and these health actions for prevent sick creates better choices, especially brand choice (e.g., Becker et al., 1974; Janz \& Becker, 1984; Narayana, 2009). In other words, the health belief model theory supports the $\mathrm{HC}$ and brand choice and therefore, this study makes link between the $\mathrm{HC}$ and CBBE by using this model.

Importantly, there is a growing segment of health conscious consumers across the world (Kemp \& Bui, 2011). Even though consumers are more concerned of their health, Zsolt (2012) implies that the choices of branded products are healthier than unbranded products. Therefore, it is notable that these health conscious consumers have the motivation to purchase the products, which have strong brand name in order to improve the quality of life and this is particularly true in the food and beverage industry (Kemp \& Bui, 2011). Indeed, consumers go for the branded products due to the $\mathrm{HC}$ and reduce the perceive risk of health (e.g., Kemp \& Bui, 2011; Orth, 2006; Tikász, Szûcs \& Stündl, 2009), it is perhaps according to the health belief model theory (Janz \& Becker, 1984).

Nevertheless, Coca Cola and Pepsi Cola have more global brand value and they are ranked first and second respectively, within the global carbonated beverage industry in 2014 (Forbes, 2014). Notably, Coca Cola, Elephant House and Pepsi Cola had more brand value within the carbonated soft drink industry in Sri Lanka in 2014 (Brand Finance Lanka, 2014). According to Kamakura and Russell (1993) higher level of brand value is vital for the creation of CBBE at a higher degree. Though, consumers have more $\mathrm{HC}$ towards the consumption of carbonated soft drinks (Lőrinczi et al., 2009), the brands like Coca Cola, Elephant House and Pepsi Cola assist to preserve the $\mathrm{HC}$ unambiguously and reduce the health risk of the consumers, since these brands have high brand value. This unambiguous support of its brands for the HC (e.g., Narayana, 2009) will lead to an increase in CBBE (e.g., Dawar, 1998; Dawar \& Pillutla, 2000) and this link is further supported by health belief model (e.g., Becker et al., 1974; Janz \& Becker, 1984; Narayana, 2009).

Therefore, based on the preceding discussion on health belief model theory and brand value concept the researcher assumes that $\mathrm{HC}$ may positively impact on CBBE, especially in the carbonated soft drink industry among the educated youth generation in Sri Lanka.

H3: The degree of youth educated consumers' HC has a significant positive impact on the degree of their perceived evaluation of brand equity in the carbonated soft drink industry in Sri Lanka.

\subsection{Conceptual Framework}

The conceptual framework is depicted in the Figure 1 that is based on the Gould $(1988,1990)$ HC model, Aaker (1991) CBBE model, and health belief model theory and brand value concept. Indeed, the health belief model theory from psychological and behavioral theory and value concept are used to explain the relationship between $\mathrm{HC}$ and $\mathrm{CBBE}$ 


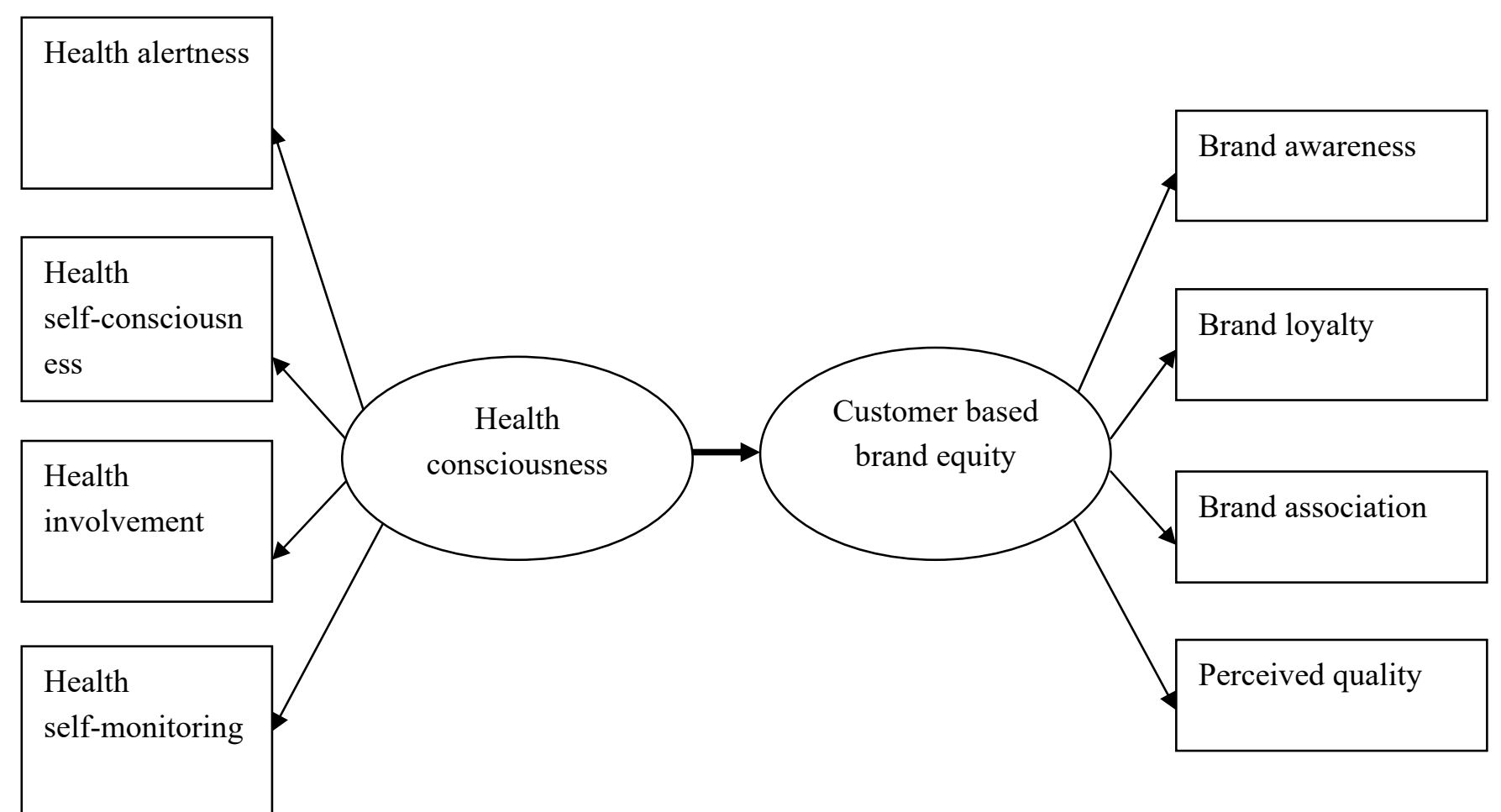

Figure 1. Conceptual Framework

\section{Methodology}

\subsection{Measures and Measurement}

The HC and CBBE were measured by means of the scales developed in the literature. In fact, to measure the HC a nine item scale were used, consisting of four sub-dimensions namely, health alertness, health self-consciousness, health involvement and health self-monitoring, which was developed by Gould (1988, 1990). Further, CBBE was treated as a four dimensional construct encompasses of brand awareness, brand association, perceived quality and brand loyalty (Aaker, 1991). Brand awareness was measured using a 3-item scale adapted from the branding literature (Yoo \& Donthu, 2001). Brand association-a 4-item scale was adapted from brand equity literature (Aaker, 1991). Perceived quality was measured using a 4-item scale adapted from the branding literatures (Aaker, 1991; Yoo \& Donthu, 2001 both as cite in Spry, Pappu \& Cornwell, 2011). Finally, brand loyalty was measured using a 3-item scale from the work of Yoo and Donthu (2001).

The measurement scales for the HC and CBBE constructs (23 items) were used to develop a questionnaire in English. All the items were measured on a five-point Likert scale with anchors of strongly disagree (1) and strongly agree (5). The final section of the questionnaire consisted questions related to the respondents' demographic characteristics including, gender, age and parental income.

\subsection{Pre-test}

A pre-test of the questionnaire with 23 items was conducted prior to the actual study by six marketing academics and six marketing managers. Based on these twelve experts' comments, the wording and layout of the questions were rearranged. Then, the main study followed with 23 items.

\subsection{Sample Section and Data Collection}

Previous carbonated soft drink related studies considered educated youth generation as target population, especially university undergraduate students (Atilgan et al., 2005; Netemeyer et al., 2004). As consistent with previous studies, this study also considered educated youth generation studying in Sri Lankan universities (undergraduate students) who has consumed carbonated soft drinks as target population, using a judgmental sampling method. Accordingly, a total of 381 copies of questionnaires were distributed, and after deleting data with missing values, 338 responses were found usable, yielding an 89 per cent response rate. 


\subsection{Statistical Treatment of Data}

This study used one sample t-test at the 0.05 significance level to test the hypotheses $\mathrm{H} 1$ and $\mathrm{H} 2$, and simple linear regression analysis was used to test the hypothesis H3 with SPSS version 22.0. In addition, the mean scores of the 5-point Likert scale measurement (mean scores for low level, moderate level and high level are between 1 and 2.49, 2.5 and 3.49 and 3.5 and 5, respectively) were adopted from Hair, Black, Babin, Anderson and Tatham (2006) to determine the degree of HC and CBBE (e.g., Thusyanthy \& Senthilnathan, 2013; Thusyanthy \& Tharanikaran, 2015; Thusyanthy, 2016) in the one sample t-test statistical analysis.

\section{Data Analysis and Results}

\subsection{Sample Profile}

The details of 338 respondents are represented in Table 1. A large proportion of respondents (40.72 per cent) fell between the 20 and 23 age group and about 57 per cent were male. Most of the respondents' parents (43.79 per cent) had monthly income 100000 - 169000; 13.61 per cent, less than 30000; 23.96 per cent, 30000 - 99000; and 18.64 per cent, above 170000 .

Table 1. Demographic profile of respondent

\begin{tabular}{lll}
\hline Classification & Frequency & Per Cent \\
\hline Gender & 192 & \\
Male & 146 & 56.80 \\
Female & & 43.20 \\
Age group & 94 & \\
$18-20$ & 103 & 27.81 \\
$20-23$ & 141 & 30.47 \\
$24-26$ & & 41.72 \\
Parents income level & 46 & \\
$<30000$ & 81 & 13.61 \\
$30000-99000$ & 148 & 23.96 \\
$100000-169000$ & 63 & 43.79 \\
$>170000$ & & 18.64 \\
\hline
\end{tabular}

\subsection{Unidimensionality, Reliability and Validity Assessment}

Unidimensionality of $\mathrm{HC}$ and $\mathrm{CBBE}$ was assessed using principal component factor analysis with Varimax rotation. In fact, as preliminary to conduct factor analysis the data from the study were subject to two tests. Accordingly, the SPSS version 22.0 output for Kaiser-Meyer-Olkin (KMO) test (0.814) and Bartlett's test of Sphericity $\left(\chi^{2}=2603.56, p<0.000, \mathrm{df}=253\right)$ were ensured the sampling adequacy and the appropriateness of the factor analysis, respectively. After determining sampling adequacy and the appropriateness of the factor analysis, 338 samples in this study were also subject to factor analysis (through principle component analysis with Varimax rotation procedure) in order to explore the unidimensionality of each scale by applying SPSS version 22.0 (see Table 2). All the items for both $\mathrm{HC}$ and CBBE were factor loaded, ranging from 0.657 to 0.895 , exceeding the critical level of 0.4 (Bagozzi \& Baumgartner, 1994) and thus, no necessity for eliminating any items and ensured the acceptable level of unidimensionality.

Reliability of each scale was verified through Cronbach's alpha coefficient (Churchill, 1979). Cronbach's alpha for each dimension ranged from 0.669 to 0.758 , exceeding the threshold value of 0.60 (Churchill, 1979; Thusyanthy \& Senthilnathan, 2012 cite Godard, Ehlinger \& Grenier, 2001) and therefore, provided satisfactory reliability for the dimensions (see Table 2).

Sekaran and Bougie (2010) classify the validity into two major categories namely, content validity and construct validity. According to Rossiter (2002) content validity is a priori evidence that the items are a good way representation of the construct. To ensure the content validity, scale development procedure for HC, and CBBE that were guided by the existing scaling literature (Aaker, 1991; Gould, 1988, 1990; Yoo \& Donthu, 2001). Further, Westen and Rosenthal (2003) define construct validity as 'the extent to which a measure adequately assesses the construct it purports to assess'. In addition, construct validity is assessed through convergent and discriminant validities. As consistent with past studies, this study also used Construct Reliability (CR) and Average Variance Extracted (AVE) to assess the convergent validity (Zdravkovic, Magnusson \& Stanle, 2010). 
Accordingly, CR and AVE for all dimensions were well above the recommended levels of 0.7 (Tharanikaran, Sritharan \& Thusyanthy 2017 cite Fornell \& Larcker, 1981) and 0.5 (Tharanikaran, Sritharan \& Thusyanthy 2017 cite Hair, Anderson, Tatham \& Black, 1998), respectively, providing strong evidence of convergent validity (see Table 2).

Table 2. Unidimensionality, reliability and convergent validity assessment

\begin{tabular}{|c|c|c|c|}
\hline \multicolumn{2}{|l|}{ Construct } & \multirow{2}{*}{$\begin{array}{l}\text { Statement } \\
\text { Alert to changes health while consuming the product category }\end{array}$} & \multirow{2}{*}{$\frac{\text { FL }}{0.88}$} \\
\hline Health & Health alertness & & \\
\hline \multirow[t]{12}{*}{ consciousness } & $\operatorname{AVE}(0.67)$ & Usually aware of health while consuming the product category & 0.75 \\
\hline & $\mathrm{CR}(0.84)$ & & \\
\hline & $\alpha=0.69$ & & \\
\hline & Health self-consciousness & Reflect health while consuming the product category & 0.77 \\
\hline & $\operatorname{AVE}(0.57)$ & Self-conscious about health while consuming the product category & 0.74 \\
\hline & $\begin{array}{l}\mathrm{CR}(0.83) \\
\alpha=0.75\end{array}$ & $\begin{array}{l}\text { Attentive to inner feelings about health while consuming the product } \\
\text { category }\end{array}$ & 0.76 \\
\hline & Health involvement & Constantly examining health due to the consumption of product category & 0.87 \\
\hline & $\operatorname{AVE}(0.69)$ & Involvement with health while consuming the product category & 0.79 \\
\hline & CR (0.84), & & \\
\hline & $\alpha=0.75$ & & \\
\hline & $\begin{array}{l}\text { Health self-monitoring } \\
\text { AVE }(0.63) \text {, }\end{array}$ & $\begin{array}{l}\text { Aware of the state of health while consuming the product category as go } \\
\text { through the day }\end{array}$ & 0.67 \\
\hline & $\begin{array}{l}\mathrm{CR}(0.83) \\
\alpha=0.67\end{array}$ & $\begin{array}{l}\text { Physically feel while consuming the product category as go through the } \\
\text { day }\end{array}$ & 0.90 \\
\hline \multirow[t]{14}{*}{$\begin{array}{l}\text { Customer based brand } \\
\text { equity }\end{array}$} & $\begin{array}{l}\text { Brand awareness AVE } \\
(0.59),\end{array}$ & $\begin{array}{l}\text { Recognize particular brand among other competing brands of carbonated } \\
\text { soft drinks. }\end{array}$ & 0.78 \\
\hline & $\mathrm{CR}(0.81)$ & Aware of particular brand among carbonated soft drinks. & 0.76 \\
\hline & $\alpha=0.73$ & $\begin{array}{l}\text { Characteristics of particular brand in the carbonated soft drinks come to } \\
\text { the mind quickly. }\end{array}$ & 0.77 \\
\hline & $\begin{array}{l}\text { Brand association AVE } \\
(0.53) \text {, }\end{array}$ & $\begin{array}{l}\text { Particular brand among the carbonated soft drinks offer good value for } \\
\text { money. }\end{array}$ & 0.70 \\
\hline & CR (0.78), & Like particular brand among the carbonated soft drinks. & 0.75 \\
\hline & $\alpha=0.73$ & Trust particular brand as a manufacturer of carbonated soft drinks. & 0.74 \\
\hline & & $\begin{array}{l}\text { Quickly recall the symbol or logo of particular brand of carbonated soft } \\
\text { drinks. }\end{array}$ & 0.72 \\
\hline & Perceived quality AVE & Quality of particular brand in the product category is extremely high & 0.66 \\
\hline & $(0.53)$ & Brand in the product category is very consistent quality & 0.74 \\
\hline & CR (0.83), & Particular brand in the product category offer excellent features & 0.76 \\
\hline & $\alpha=0.76$ & Particular brand in the product category is very reliable & 0.75 \\
\hline & $\begin{array}{l}\text { Brand loyalty AVE }(0.61) \\
\text { CR }(0.79)\end{array}$ & $\begin{array}{l}\text { Loyal to particular brand when considering the purchase of carbonated soft } \\
\text { drinks. }\end{array}$ & 0.80 \\
\hline & $\alpha=0.76$ & $\begin{array}{l}\text { Particular brand would be the first choice when considering the purchase } \\
\text { of carbonated soft drinks. }\end{array}$ & 0.83 \\
\hline & & $\begin{array}{l}\text { Not buy other brands of carbonated soft drinks if particular brand is } \\
\text { available at the store. }\end{array}$ & 0.71 \\
\hline
\end{tabular}

Note. AVE, average variance extracted; CR, construct reliability; $\alpha$, Cronbach's alpha.

Discriminant validity can be established if the AVE value for a construct/dimension should be substantially higher than the squared correlation of two constructs/dimensions (Fornell \& Larcker, 1981). As can be seen in Table 3, according to Fornell and Larcker (1981) the discriminant validity was established, since the AVE values associated with all dimensions $(0.53<$ AVE value $<0.69)$ were greater than the squared correlation between dimensions. Moreover, Table 3 also reported the means and standard deviations for all dimensions and constructs. The means for the dimensions range from 2.35 to 2.72 (out of 5) and corresponding standard deviation range from 0.45 to 0.75 . 
Table 3. Descriptive statistics and correlation metrics

\begin{tabular}{|c|c|c|c|c|c|c|c|c|c|c|}
\hline D & M & SD & HA & HS & HI & HSM & BA & BAS & PQ & BL \\
\hline HA & 2.59 & 0.65 & 0.67 & & & & & & & \\
\hline HS & 2.35 & 0.69 & $0.48^{* *}$ & 0.57 & & & & & & \\
\hline HI & 2.38 & 0.75 & $0.33^{* *}$ & $0.39 * *$ & 0.69 & & & & & \\
\hline HSM & 2.48 & 0.70 & $0.31 * *$ & $0.39 * *$ & $0.38 * *$ & 0.63 & & & & \\
\hline BA & 2.63 & 0.57 & $0.22 * *$ & $0.14 * *$ & $0.02^{\text {n.s. }}$ & $0.04^{\text {n.s. }}$ & 0.59 & & & \\
\hline BAS & 2.72 & 0.45 & $0.05^{\text {n.s. }}$ & $0.01^{\text {n.s. }}$ & $-0.01^{\text {n.s. }}$ & $-0.01^{\text {n.s. }}$ & $0.18^{* *}$ & 0.53 & & \\
\hline PQ & 2.56 & 0.57 & $0.06^{\text {n.s. }}$ & $0.05^{\text {n.s. }}$ & $0.06^{\text {n.s. }}$ & $0.09^{\text {n.s. }}$ & $0.13^{*}$ & $0.26^{* *}$ & 0.53 & \\
\hline BL & 2.56 & 0.60 & $0.02^{\text {n.s. }}$ & $0.05^{\text {n.s. }}$ & $0.04^{\text {n.s. }}$ & $0.06^{\text {n.s. }}$ & $0.24 * *$ & $0.19 * *$ & $0.32 * *$ & 0.61 \\
\hline $\mathrm{HC}$ & 2.40 & 0.65 & & & & & & & & \\
\hline $\mathrm{BE}$ & 2.62 & 0.49 & & & & & & & & \\
\hline
\end{tabular}

Note. D, dimension; M, mean score; SD, standard deviation; HC, health consciousness; BE, CBBE; HA, health alertness; HS, health self-consciousness; HI, health involvement; HSM, health-self monitoring; BA, brand awareness; BAS, brand association; PQ, perceived quality; BL, brand loyalty; n.s., not significant; values on the diagonal in bold indicate the average variance extracted for the dimensions; the scores in the lower diagonal are Pearson correlations and ${ }^{*} p<0.01,{ }^{*} p<0.05$ (two-tailed).

\subsection{Test of Hypotheses}

H1 and H2 were tested using one sample t-test (see Table 4). The decision criteria for low level (between 1 and 2.49), moderate level (2.5 and 3.49) and high level (3.5 and 5) were adopted to determine the degree of youth educated consumers' perceived evaluation on $\mathrm{HC}$ and brand equity in the carbonated soft drink industry in Sri Lanka.

Table 4. One sample T-test results

\begin{tabular}{|c|c|c|c|c|c|c|c|}
\hline \multirow[t]{2}{*}{ Variable } & \multicolumn{2}{|c|}{ Assumed mean } & \multirow{2}{*}{$\begin{array}{l}\text { Observed } \\
\text { mean }\end{array}$} & \multicolumn{2}{|c|}{ t-value } & \multicolumn{2}{|c|}{ Sig.level } \\
\hline & LB & UB & & LB & UB & LB & UB \\
\hline Health consciousness & 1 & 2.5 & 2.40 & 39.54 & -2.75 & 0.000 & 0.000 \\
\hline Customer based brand equity & 2.5 & 3.5 & 2.62 & 4.42 & -32.90 & 0.000 & 0.000 \\
\hline
\end{tabular}

Note. LB, lower boundary; UB, upper boundary.

As indicated in the Table 4, significance values of 0.000 for both lower and upper boundaries (i.e., $p<0.05$ ) in $\mathrm{HC}$ and $\mathrm{CBBE}$ shows that there are significance differences between assumed means and observed means. Clearly, the observed mean 2.40 for $\mathrm{HC}$ has fallen the low level range of $1-2.5$, while observed mean 2.62 for $\mathrm{CBBE}$ has fallen the moderate level range of 2.5 - 3.5. Hence, the degree of youth educated consumers' perceived evaluation on $\mathrm{HC}$ and brand equity are in low level and moderate level, respectively in the carbonated industry in Sri Lanka (Thusyanthy, 2016). Notably, the one sample- t-test failed to offer support for H1 and H2.

To test H3 simple linear regression analysis was performed (see Table 5). As can be seen in Table 5, approximately only 4 per cent of the observed variability of CBBE (adjusted $\mathrm{R}^{2}=0.038$ ) was explained by $\mathrm{HC}$. However, this simple linear regression equation was found significant $(\mathrm{F}=14.350, p<0.05)$. Further, the youth educated consumers' perceived evaluation of $\mathrm{HC}$ has significantly positive impact on their brand equity by 15.3 per cent $(\beta=2.251 ; p<0.05)$. Thus, it supports the H3.

Table 5. Simple linear regression analysis results

\begin{tabular}{|c|c|c|c|c|c|c|c|}
\hline DV & IV & Adjusted $\mathbf{R}^{2}$ & Beta & t-value & Sig. value & F-value & Sig. value \\
\hline \multirow[t]{2}{*}{$\mathrm{BE}$} & Constant & 0.038 & $2.251^{*}$ & 22.408 & 0.000 & 14.350 & 0.000 \\
\hline & $\mathrm{HC}$ & & $0.153^{*}$ & 3.788 & 0.000 & & \\
\hline
\end{tabular}

Note. DV, dependent variable; IV, independent variable; BE, customer based brand equity; HC, health consciousness; i, 1, 2, 3, ......, 338; SE, standard error; $\mathrm{R}^{2,}$ squares of the correlations; $* p<0.05$. 


\section{Discussion}

\subsection{Theoretical Implications}

$\mathrm{H} 1$ predicted the degree of youth educated consumers' HC is at a high level in the carbonated soft drink industry in Sri Lanka. H1 was not supported. There is a possible explanation for this result. This study considered educated youth generation as target population in Sri Lanka, since this youth generation like to drink more carbonated soft drink beverages (Cuomo, Sarnelli, Savarese \& Buyckx, 2009), and thus, they might less concern their health. However, the HC might have been at a high level, if the target population is selected from the whole Sri Lankan consumers. Nevertheless, this study offers the empirical support to close the first gap. Consequently, the answer gets for the first research question is that the $\mathrm{HC}$ at a low level in the carbonated soft drink industry in Sri Lanka, especially among the educated youth generation.

$\mathrm{H} 2$ predicted that the degree of youth educated consumers' perceived evaluation on brand equity is at a higher level in the carbonated soft drink industry in Sri Lanka; however there was no support for H2. Even though the results suggested that the degree of youth educated consumers' perceived evaluation on brand equity is at a moderate level in the carbonated soft drink industry in Sri Lanka, the literature offers strong support for CBBE high level in the carbonated soft drink industry in various countries (Atilgan et al., 2005; Huang \& Liu, 2014; Waris, 2013). There is possible reason for this explanation for this result. This study considered educated youth generation as target population, since they might have consider the brand equity moderate level. The CBBE might have had high level, if the target population was the whole Sri Lankan consumers. Nevertheless, this empirical study offers the support to close the gap two, and the answer gets for the second research question is that the CBBE is at a moderate level in the carbonated soft drink industry in Sri Lanka, especially among the educated youth generation.

A result confirming the degree of youth educated consumers' HC has a significant positive impact on the degree of their perceived evaluation of brand equity in the carbonated soft drink industry in Sri Lanka, hypothesized in H3. In other words, this study offers empirical support for previously theorized relationship between HC and CBBE in accordance with the health belief model theory and brand value concept. In fact, health belief model theory is used to make a link between HC and CBBE (Narayana, 2009), since the people take action to prevent illness via choices, especially brand choices (e.g., Becker et al., 1974; Narayana, 2009). Nevertheless, consumers go for the branded products due to the HC and reduce the perceive risk of health (e.g., Kemp \& Bui, 2011; Orth, 2006), and thus consumers purchase the products which has high brand value. Kamakura and Russell (1993) argues that higher level of brand value is vital for the creation of CBBE at a higher degree. Therefore, the both health belief model and brand value concept were used to make the link between HC and CBBE. Notably, the hypothesis testing results for the $\mathrm{H} 3$ revealed that it is consistent with the theory of health belief model and brand value concept. Therefore, this study offers the empirical support to close the third gap and assists to get the answer for the third research question.

\subsection{Managerial Implications}

The findings of this study have important implications for the marketing managers in the carbonated soft drink industry in Sri Lanka. The present study indicates that the degree of youth educated consumers' perceived evaluation of heath consciousness and brand equity are in the low level and moderate level, respectively in the carbonated soft drink industry in Sri Lanka. However, the consumption of carbonated soft drinks harmful impact to the human body (Assy et al., 2008; Palmer et al., 2008), the educated youth generation in Sri Lanka less concern their health, since $\mathrm{HC}$ is high, related to the consumption of carbonated soft drinks in the various countries (Lörinczi et al., 2009). It is the positive sign to the marketing managers who are in the carbonated soft drink industry to target this educated youth generation. In addition, CBBE also very crucial in the carbonated soft drink industry in Sri Lanka (Huang \& Liu, 2014; Waris, 2013), however youth educated consumers' perceived evaluation of brand equity in moderate level. Therefore, the marketing managers in this industry should concentrate these findings try to build CBBE at a high level to get the sustainable competitive advantage among the educated youth generation in Sri Lanka.

Even though, the degree of youth educated consumers' HC at low level in the carbonated soft drinks industry among the educated youth generation in Sri Lanka, the youth educated consumers' HC significantly impact on their perceived evaluation of brand equity. Hence, the marketing managers should consider the health of the educated youth generation, since this generation also may highly concern their health in future and thus, it might negatively impact the CBBE in long-term. As a result, this study suggests that marketing managers should develop effective marketing strategies to concern the long-term impact of health for the educated youth generation as well as the other consumers and potential consumers of the carbonated soft drinks. 


\section{Limitations and Future Research Directions}

The current study examined only the educated youth generation in Sri Lankan universities. Therefore, the main limitation was related to the generalization of the findings due to the usage of student sample, since this sample has unique characteristics and non-representativeness of the population and thus, threatens the external validity (Zdravkovic et al., 2010). As consistent with the previous studies this study also used the students sample as replication to the existing literature (Fives, Hammana \& Olivarez, 2007). However, future research can be conducted to cover the consumers in different part in Sri Lanka, including rural and urban areas. Second, this study only identifies the impact of $\mathrm{HC}$ on CBBE. Thus, the further research can be incorporated other variables, along with the $\mathrm{HC}$ and $\mathrm{CBBE}$.

\section{References}

Aaker, D. A. (1991). Managing brand equity. New York: Free Press.

Assy, N., Nasser, G., Kamayse, I., Nseir, W., Beniashvili, Z., Djibre, A., \& Grosovski, M. (2008). Soft drink consumption linked with fatty liver in the absence of traditional risk factors. Canadian Journal of Gastroenterology, 22(10), 811-816.

Atilgan, E., Safak, A., \& Serekan, A. (2005). Determinants of the brand equity: A verification approach in the beverage industry in Turkey. Marketing Intelligence and Planning, 23(3), 237-248. https://doi.org/10.1108/02634500510597283

Bagozzi, R. P., \& Baumgartner, H. (1994). The evaluation of structural equation models and hypothesis testing. In R. P., Bagozzi (Ed.), Principles of marketing research (pp. 386-422). Cambridge: Blackwell Publishers.

Becker, M. H., Drachman, R. H., \& Kirscht, J. P. (1974). A new approach to explaining sick-role behavior in low-income populations. American Journal of Public Health, 64(3), 205-216.

Bhangale, S. (2011). Health consciousness among tribal and rural population. Indian Streams Research Journal, $1(2), 37-41$

Bloomberg. (2011). Research and markets: In 2014, the global soft drink market is. Retrieved 10 September 2016, from http://www.bloomberg.com/apps/news?pid=conewsstory\&tkr=KO:AR\&sid=aZ4BSchtab9I

Brand Finance Lanka. (2014). Most valuable brands. Retrieved 23 September 2016, from http://www.stingconsultants.com/pdf/Most-Valuable-Brands-table.pdf

Bruce, B. (2011). Could Kik Cola do well against Coke and Pepsi in Sri Lanka? Retrieved 10 September 2016, from http://www.foodbev.com/news/can-kik-cola-kick-coke-and-pepsi-in-sri-lanka\#.VFuMHfmUd5A

Cader, S. (2014). SL shifting towards premiumisation-Nielsen SL Chief. Daily Mirror, Retrieved 20 September 2016 , from http://www.dailymirror.lk/business/features/51506-sl-shifting-towards-premiumisation--nielsen-sl-chief-.ht $\mathrm{ml}$

Central Bank of Sri Lanka. (2011). Annual Report, (Cabraal, AN, Governor), Colombo.

Churchill, G. A. (1979). A paradigm for developing better measures of marketing constructs. Journal of Marketing Research, 16(1), 64-73. http://www.jstor.org/stable/3150876

Cuomo, R., Sarnelli, G., Savarese, M. F., \& Buyckx, M. (2009). Carbonated beverages and gastrointestinal system: Between myth and reality. Nutrition, Metabolism \& Cardiovascular Diseases, 19(10), 683-689. https://doi.org/10.1016/j.numecd.2009.03.020

Davis, J. N., Ventura, E. E., Weigensberg, M. J., Ball, G. D. C., Cruz, M. L., Shaibi, G. Q., \& Goran, M. I. (2005) The relation of sugar intake to beta cell function in overweight Latino children. American Journal of Clinical Nutrition, 82(5), 1004-1010.

Dawar, N. (1998). Product-harm crises and the signaling ability of brands. International Studies of Management and organization, 28(3), 109-119. Retrieved from http://www.jstor.org/stable/40397416

Dawar, N., \& Pillutla, M. M. (2000). Impact of product-harm crises on brand equity: The moderating role of consumer expectations. Journal of Marketing Research, 37(2), 215-226. http://www.jstor.org/stable/1558501

Fives, H., Hammana, D., \& Olivarez, A. (2007). Does burnout begin with student-teaching? Analyzing efficacy, burnout, and support during the student-teaching semester. Teaching and Teacher Education, 23(6), 916-934. https://doi.org/10.1016/j.tate.2006.03.013 
Forbes. (2014). The world's most valuable brands. Retrieved 28 September 2016, from http://www.forbes.com/powerful-brands/list/\#page:1_sort:0_direction:asc_search

Fornell, C., \& Larcker, D.F. (1981). Structural equation models with unobservable variables and measurement error-algebra and statistics. Journal of Marketing Research, 18(3), 382-388. Retrieved from http://www.jstor.org/stable/3150980

Gehlhar, M., \& Regmi, A. (2005). Factors shaping global food markets. In A. Regmiand and M. Gehlhar (Eds.), New Directions in Global Food Markets (pp. 5-17), United States Department of Agriculture.

Glanz, K., \& Rimer. (1995). Theory at a glance: A guide to health promotion practice (2nd ed.). Bethesda: National Cancer Institute.

Gould, S. J. (1988). Consumer attitudes toward health and health care: A differential perspective. Journal of Consumer Affairs, 22(1), 96-118. https://doi.org/10.1111/j.1745-6606.1988.tb00215.x

Gould, S. J. (1990). Health consciousness and health behavior: The application of a new health consciousness scale. American Journal of Preventive Medicine, 6(4), 228-237.

Haigh, D. (1999). Understanding the financial value of brands. Brussels: European Association of Advertising Agencies.

Hair, J., Black, B., Babin, B., Anderson, R., \& Tatham, R. (2006). Multivariate data analysis. Upper saddle river: Pearson Prentice Hall.

Hu, F. B., \& Malik, V. S. (2010). Sugar-sweetened beverages and risk of obesity and type 2 diabetes: Epidemiologic evidence. Physiology and Behavior, 100(1), 47-54. https://doi.org/10.1016/j.physbeh.2010.01.036

Huang, L., \& Liu, Y. (2014). The dynamics of brand value in the carbonated soft drinks industry. Paper presented at the annual meeting of the Agricultural and Applied Economics Association, Minneapolis.

Janz, N. K., \& Becker, M. H. (1984). The health belief model a decade later. Health Education Quarterly, 11(1), 1-47. https://doi.org/10.1177/109019818401100101

Kamakura, W. A., \& Russell, G. J. (1993). Measuring brand value with scanner data. International Journal of Research in Marketing, 10(1), 9-22. https://doi.org/10.1016/0167-8116(93)90030-3

Keller, K. L. (2003). Understanding brands, branding, and brand equity. Interactive Marketing, 5(1), 7-20. https://doi.org/10.1057/palgrave.im.4340213

Kemp, E., \& Bui, M. (2011). Healthy brands: Establishing brand credibility, commitment and connection among consumers. Journal of Consumer Marketing, 28(6), 429-437. https://doi.org/10.1108/07363761111165949

Leatherhead Food Research. (2014). Soft drinks microbiology. Retrieved 10 September 2016, from http://www.leatherheadfood.com/soft-drinks-microbiology.

Lörinczi, K., Zoltán, B. \& Nagy, A. S. (2009). Hungarian consumer behavior analysis in terms of healthy nutrition. Paper presented at the seminar of the EAAE, Greece.

Mendis, C. (2012). Three icons form Beverage Association of Sri Lanka. Daily Financial Times. Retrieved 11 September 2016, from http://www.ft.lk/2012/08/09/three-icons-form-beverage-association-of-sri-lanka/.

Narayana, N. V. V. S. (2009). Development of health consciousness scale. Journal of Indian Health Psychology, $3(2), 87-102$.

Netemeyer, R. G., Krishnan, B., Pullig, C., Wang, G., Yagci, M., Dean, D., Ricks, J., \& Wirth, F. (2004). Developing and validating measures of facets of customer-based brand equity. Journal of Business Research, 57(2), 209-224. https://doi.org/10.1016/S0148-2963(01)00303-4

NIIR Project Consultancy Services. (2012). Soft drink industry in India. Retrieved 10 September 2016, from, http://www.niir.org/information/content.phtml?content=184

Orth, U. R. (2006). Difference brands for different occasions-drivers of consumer public and private choices. Proceedings of the $3 \mathrm{rd}$ conference on international wine business research, France: Montpellier.

Palmer, J. R., Boggs, D. A., Krishnan, S., Hu, F. B., Singer, M., \& Rosenberg, L. (2008). Sugar-sweetened beverages and incidence of type 2 diabetes mellitus in African American women. Archives of Internal Medicine, 168(14), 1487-1492. https://doi.org/10.1001/archinte.168.14.1487

Pamnani, S., Pellerano, H., Sivajee, D., \& Tambiah, V. (2004). The Maharaja dilemma: Can Pepsi thrive in Sri 
Lanka? Duke University, The Fuqua School of Business.

Pappu, R., Quester, .P. G., \& Cooksey, R. W. (2006). Consumer-based brand equity and country-of-origin relationships: Some empirical evidence. European Journal of Marketing, 40(5-6), 696-717. https://doi.org/10.1108/03090560610657903

Peiris, P. (2014). Food and beverages industry will see tremendous growth in next few. Daily News. Retrieved 10 September 2016 , from http://www.dailynews.lk/?q=business/food-and-beverages-industry-will-see-tremendous-growth-next-few-y ears

Perera, P. (2012, January 18). A prediction of market trends for 2012 in a Sri Lankan context. Daily News, Retrieved 20 September 2016, from http://archives.dailynewslk/2012/01/18/bus31.asp

Pradhan, J., \& Misra, D. P. (2014). Measuring customer based brand equities of FMCGs in Indian rural markets-an empirical study. International Journal of Business and Management Invention, 3(1), 51-62.

Rosenstock, I. M. (1974). The health belief model and preventive health behavior. Health Education Monographs, 2(4), 354-386.

Rosenstock, I. M., Strecher, V. J., \& Becker, M. H. (1988). Social learning theory and the health belief model. Health Education Quarterly, 15(2), 175-183.

Rossiter, J. R. (2002). The C-OAR-SE procedure for scale development in marketing. International Journal of Research in Marketing, 19(4), 305-335. https://doi.org/10.1016/S0167-8116(02)00097-6

Sekaran, U., \& Bougie, R. (2010). Research methods for business: A skill building approach (5th ed.). India: Wiley India Pvt. Ltd.

Shavitt, S., Torelli, C. J., \& Wong, J. (2009). Identity-based motivation: Constraints and opportunities in consumer research. Journal of Consumer Psychology, 19(3), 261-266. https://doi.org/10.1016/j.jcps.2009.05.009

Spry, A., Pappu, R., \& Cornwell, T. B. (2011). Celebrity endorsement, brand credibility and brand equity. European Journal of Marketing, 45(6), 882-909. https://doi.org/10.1108/03090561111119958

Tharanikaran, V., Sritharan, S., \& Thusyanthy, V. (2017). Service quality and customer satisfaction in the electronic banking. International Journal of Business and Management, 12(4), 67-83. https://doi.org/10.5539/ijbm.v12n4p67

The Sunday Leader. (2010). Pepsi's rights sold for \$15mn. Retrieved 0511 September 2016, from http://www.thesundayleader.lk/2010/12/26/pepsi\%E2\%80\%99s-rights-sold-for-15-mn/.

Thusyanthy, V. (2016, June). Assessing the levels of health consciousness and customer based brand equity in Sri Lanka. Proceedings of Research Conference on Business Studies, Vavuniya Campus of the University of Jaffna, Sri Lanka.

Thusyanthy, V., \& Senthilnathan, S. (2012). Customer satisfaction in terms of physical evidence and employee interaction. IUP Journal of Marketing Management, 11(3), 7-24.

Thusyanthy, V., \& Senthilnathan, S. (2013). Level of job satisfaction and its association with demographic variables. IME Journal, 7(2), 39-45.

Thusyanthy, V., \& Tharanikaran, V. (2015). The relationship variables to celebrity endorsement and brand equity: A comprehensive review. International Journal of Business and Management, 10(11), 212-221. http://dx.doi.org/10.5539/ijbm.v10n11p212

Waris, I. (2013). Consumers' perception about brand equity of carbonated drinks in Karachi. Annual Research Journal GIDROSHIA, 1(1), 19-32.

Westen, D., \& Rosenthal, R. (2003). Quantifying construct validity: Two simple measures. Journal of Personality and Social Psychology, 84(3), 608-618. https://doi.org/10.1037/0022-3514.84.3.608

Yoo, B., \& Donthu, N. (2001). Developing and validating a multidimensional consumer-based brand equity scale. Journal of Business Research, 52(1), 1-14. https://doi.org/10.1016/S0148-2963(99)00098-3

Zdravkovic, S., Magnusson, P., \& Stanley, S. M. (2010). Dimensions of fit between a brand and a social cause and their influence on attitudes. International Journal of Research in Marketing, 27(2), 151-160. https://doi.org/10.1016/j.ijresmar.2010.01.005 
Zsolt, S. (2012). The consumption of branded meat products in Hungary (Unpublished doctorial thesis). Szent Istvan University.

\section{Copyrights}

Copyright for this article is retained by the author(s), with first publication rights granted to the journal.

This is an open-access article distributed under the terms and conditions of the Creative Commons Attribution license (http://creativecommons.org/licenses/by/4.0/). 